$\begin{array}{ccc}\text { Tersedia online di: http://ejournal-balitbang.kkp.go.id/index.php/jppi } & \text { JURNAL } \\ \text { e-mail:jppi.puslitbangkan@ gmail.com } & \text { PENELITIAN } \\ \text { PERIKANAN } & \text { INDONESIA } \\ \text { JURNAL PENELITIANPERIKANANINDONESIA } & \text { Volume 23 Nomor 2 Juni 2017 } \\ \text { e-ISSN: 2502-6542 } & \\ \text { Nomor Akreditasi: 653/AU3/P2MI-LIPI/07/2015 }\end{array}$

\title{
KOMPOSISI HASIL TANGKAPAN DAN DAERAH PENANGKAPAN HIU BOTOL (Centrophoridae) YANG DIDARATKAN DI TENAU, NUSA TENGGARA TIMUR
}

\section{CATCH COMPOSITION AND FISHING GROUND OF DOGFISH SHARK (Centrophoridae) LANDED IN THE TENAU, EAST NUSA TENGGARA}

\author{
Andrias S. Samusamu*1 dan Dharmadi ${ }^{\star 1}$ \\ ${ }^{1}$ Pusat Riset Perikanan, Ancol Jakarta, Gedung BRSDM KP II, JI. Pasir Putih II, Ancol Timur, Jakarta Utara, \\ Indonesia-14430 \\ Teregistrasi I tanggal: 08 Desember 2016; Diterima setelah perbaikan tanggal: 27 Juli 2017; \\ Disetujui terbit tanggal: 21 Agustus 2017
}

\begin{abstract}
ABSTRAK
Hiu botol merupakan jenis ikan hiu yang bernilai ekonomis tinggi, karena dapat menghasilkan minyak ikan dari ekstrak hati dinamakan squalen. Pada umumnya, hiu botol hidup di perairan Samudera Hindia pada kedalaman lebih dari 100 meter, namun sampai saat ini penyebarannya belum banyak diketahui. Selain itu, informasi terkait komposisi jenisnya masih sangat terbatas. Tulisan ini bertujuan mengkaji komposisi hiu botol yang tertangkap rawai dasar dan daerah penangkapannya di perairan Samudera Hindia yang berbasis di Kupang, Nusa Tenggara Timur. Data diperoleh dari survei lapangan dan wawancara dengan nelayan penangkap hiu di daerah Tenau, periode bulan Januari-Desember 2016. Hasil kajian menunjukkan bahwa hiu botol yang menjadi target penangkapan terdiri atas tiga jenis yaitu; Centrophorus squamosus (10-13\%), Centrophorus granulosus (15-20\%), dan Centroscymnus coelolepis (sekitar 40\%). Prosentase hiu botol yang di Samudera Hindia berkisar 0,01-0,04 \% dari total tangkapan yang didaratkan di Pelabuhan Perikanan Pantai Tenau. Sedangkan, prosentase hiu botol periode tahun 2011-2014 relatif besar dibandingkan dengan hasil tangkapan jenis hiu lainnya. Namun, pada periode 20122014 hasil tangkapan hiu botol cukup fluktuatif dan cenderung menurun. Hal ini mengindikasikan bahwa populasi sumber daya jenis hiu ini telah terjadi penurunan. Hasil tangkapan hiu botol tertinggi terjadi pada bulan Januari-Februari dan Agustus-September, yang tertangkap di wilayah perairan Selatan Pulau Rote, Timor dan Sabu. Daerah penangkapan potensial hiu botol berada pada koordinat $124^{\circ}-128^{\circ}$ BT dan $10^{\circ}-11^{\circ}$ LS pada kedalaman antara 200-800 meter.
\end{abstract}

Kata Kunci: Komposisi hasil tangkapan; daerah penangkapan hiu botol ; Samudera Hindia

\begin{abstract}
A dogfish shark has a high economic value, especially its liver oil, namely squalen. In general, a dogfish sharks live in the waters of the Indian Ocean at a depth of over 100 meters, but its distribution and composition has not been well documented. This paper aims to describe the composition of sharks caught by bottom longlines operated in the Indian Ocean landed at Kupang, East Nusa Tenggara. Data obtained from field surveys and interviews with shark fishermen from Tenau in January-December 2016. The results showed that the dogfish shark consisted of three species: Centrophorus granulosus, Centrophorus squamosus and Centroscymnus coelolepis. The percentage of dogfish sharks in the Indian Ocean ranged from 0.01 to $0.04 \%$ of the total catch landed at Tenau. While the percentage of dogfish shark in period $2011-2014$ was relatively large compared to the catch of other species of sharks. However, in period 2012 - 2014 dogfih shark catches fluctuated and tended to decrease. This indicates that the population decline of this species. The highest catches of dogfish shark occurred in January-February. During August-September sharks were caught in the territorial waters of the South Island of Rote, Timor and Sabu. Potentially
\end{abstract}


fishing areas of dogfish shark would be located at $124^{\circ}-128^{\circ} \mathrm{E}$ and $10^{\circ}-11^{\circ} \mathrm{S}$ with depths between 200-800 meters.

Keywords: Catch composition; fishing areas; dogfish shark; Indian Ocean

\section{PENDAHULUAN}

Sumberdaya hiu botol dimanfaatkan oleh masyarakat nelayan untuk meningkatkan pendapatan keluarga dan secara tidak langsung dapat menghasilkan devisa negara karena bernilai ekonomi tinggi berupa minyak yang dihasilkan dari hati ikan hiu, terutama kelompok hiu botol dari suku Squalidae dan Centrophoridae (Fahmi \& Dharmadi, 2013). Minyak yang diekstrak dari hiu botol dikenal dengan nama squalen. Vitamin $A$ dan $D$ yang terkandung dalam squalen dimanfaatkan sebagai bahan baku pada industri obat-obatan dan kosmetik. Selain itu, minyak hati hiu dari marga Centrophorus dapat dimanfaatkan sebagai bahan bakar pesawat terbang dan minyak pelumas di daerah yang dingin (Damongilala, 2008).

Bersdasarkan data statistik perikanan Provinsi Nusa Tenggara Timur (NTT) pada tahun 2014, produksi hiu sebesar $0,714 \%$ atau mencapai 814,1 ton dari total produksi perikanan. Angka produksi ini relatif lebih kecil dari angka produksi kelompok ikan demersal yaitu sebesar $42.922,2$ ton/tahun $(37,66 \%)$ dan ikan pelagis yang mencapai $60.958,9$ ton/tahun (53,48\%) (DKP Prop. NTT, 2014). Dharmadi et al., (2009) mengemukakan bahwa, hiu d NTT selain merupakan hasil tangkapan sampingan juga merupakan target tangkapan utama. Namun demikian keragaman hiu di Kupang-NTT relatif rendah jika dibandingkan dengan Kedonganan, Tanjungluar, Cilacap dan Pelabuhanratu. Di Kedonganan hiu yang ditemukan sebanyak 49 spesies. Keragaman hiu di Tanjungluar, Cilacap dan Pelabuhanratu sebanyak 47, 32 dan 27 spesies, sedangkan keragaman hiu yang ditemukan di Kupang hanya 5 spesies (Dharmadi et al, 2009).

Secara umum jenis hiu botol dalam dokumen International Union for Conservation of Nature (IUCN) tahun 2016, tergolong dalam kategori daftar merah (red list). Dari daftar tersebut sebagian besar dalam kategori hampir terancam (Near Threatened/NT) sedangkan sisanya berada dalam status rentan ( $\mathrm{Vul}$ nerable/VU), langka (Endangered/EN) sampai dengan terancam punah (Critically Endangered/CR). Pada tahun 2003, hiu botol jenis Centroscymnus coelolepis oleh IUCN telah dimasukkan dalam kategori hampir terancam (NT) sedangkan, jenis Centrophorus granulosus dan Centrophorus squamosus dikategorikan sebagai jenis yang rentan (VU) (IUCN,
2016).

Populasi hiu di seluruh negara menjadi pusat perhatian karena tingkat produktivitasnya yang rendah dan adanya kecenderungan penurunan pada populasinya (Kyne \& Simpfendorfer, 2010). Selain itu, karakteristik lainnya yang menjadikan hiu sebagai pusat perhatian adalah karena tingkat pertumbuhannya yang lambat, dan fekunditasnya yang rendah (Garcia et al., 2008; Stevens et al., 2000; Graham \& Daley, 2011). Populasi yang telah mengalami penurunan akan membutuhkan waktu puluhan tahun atau bahkan berabad-abad untuk pulih kembali (Simpfendorfer \& Kyne, 2009).

Keberadaan hiu botol di Indonesia secara spesifik belum mendapat perhatian serius dari para ilmuan maupun pembuat kebijakan. Hal ini karena masih terbatasnya hasil penelitian hiu botol yang tersedia (Dharmadi \& Fahmi, 2007a). Hiu botol memiliki kandungan minyak berkualitas tinggi yang dikenal dengan nama squalen, menjadikan hiu botol sebagai primadona sehingga eksploitasinya cenderung meningkat. Sampai saat ini penelitian tentang hiu botol di Indonesia masih sangat terbatas, sehingga perlu dilakukan penelitian lanjutan yang lebih komperhensif. Terutama, penelitian yang terkait dengan komposisi hasil tangkapan, CPUE (catch per unit effort), dan daerah penangkapannya sehingga diharapkan dapat digunakan sebagai bahan rujukan dalam pengelolaan perikanan hiu botol di Indonesia khususnya di Nusa Tengggara Timur.

\section{BAHAN DAN METODE}

Pengambilan data lapangan dilakukan di Pelabuhan Perikanan Pantai Tenau, Kota Kupang mulai Januari hingga Desember 2016. Data yang digunakan pada penelitian ini terdiri dari, data komposisi jenis ikan hiu yang didaratkan dan operasional penangkapan. Data ini diperoleh melalui wawancara dengan nahkoda dan ABK kapal rawai dasar sebanyak sepuluh orang responden. Data hasil wawancara meliputi lokasi daerah penangkapan ikan hiu dan musim penangkapan ikan hiu. Data sekunder diperoleh dari buku statistik perikanan Pelabuhan Perikanan Pantai Tenau. Data ini meliputi data produksi bulanan (tahun 2011-2014), komposisi hasil tangkapan, lokasi daerah penangkapan dan upaya penangkapan hiu dengan menggunakan rawai dasar. 
Alat tangkap yang digunakan untuk menangkap hiu botol di Kupang adalah rawai dasar, pancing ulur, jaring insang (Gill net) dan rawai tetap. Rawai dasar merupakan alat tangkap yang lebih produktif untuk menangkap hiu botol, atau dengan kata lain dapat dikatakan bahwa rawai dasar memiliki angka hasil tangkapan per unit alat (C/A) yang tertinggi. Menurut Badrudin (2015), dalam penghitungan FPI (Fishing Power Index) alat tangkap yang memiliki nilai C/A tertinggi dinyatakan sebagai alat tangkap standar. Alat tangkap dengan $\mathrm{C} /$ A tertinggi diberi indeks $\mathrm{PFI}=1$. Alat lain dikonversi ke alat tangkap ini dengan cara membagi $\mathrm{C} / \mathrm{A}$ alat lain tersebut dengan C/A alat tangkap yang tertinggi. Analisis data hasil tangkapan ikan hiu selama tahun 2011 sampai dengan 2014 dilakukan dengan menggunakan software excel. Analisis data dilakukan untuk mengetahui jumlah dan komposisi hasil tangkapan per bulan serta upaya penangkapan setiap alat tangkap. Sedangkan, peta estimasi daerah penangkapan ditampilkan berdasarkan hasil wawancara terhadap nelayan yang menangkap hiu botol sebagai target tangkapannya.

\section{HASIL DAN BAHASAN Hasil}

\section{Komposisi Jenis Hiu Botol}

Hasil tangkapan hiu yang didaratkan di Pelabuhan Perikanan Pantai Tenau berdasarkan jenisnya belum tercatat secara terperinci. Oleh karena itu, dilakukan pengamatan langsung di lapangan dengan hasil yang menunjukkan bahwa terdapat 3 (tiga) spesies hiu botol, yaitu Cokat (Centrophorus granulosus), Watanabe (Centrophorus squamosus) dan Bula-bula (Centroscymnus coelolepis). Berdasarkan hasil wawancara dengan nelayan di Tenau, ketiga jenis ini diklasifikasikan menjadi tiga kategori berdasarkan kualitas dari squalen yang dapat diekstrak. Jenis
Cokat tergolong dalam kualitas 3 (super 3), memiliki persentase hasil tangkapan per trip sebesar $15-20 \%$. Bula-bula tergolong dalam kualitas 2 (super 2) dengan persentase hasil tangkapan per trip yang tertinggi yaitu mencapai $40 \%$, sedangkan Watanabe dengan persentase hasil tangkapan sekitar 10-13\% tergolong dalam kualitas 1 (super 1). Produksi hiu botol pada tahun 2011-2014 di PPP Tenau mendominasi produksi hiu lainnya (hiu tikus dan martil) yaitu sebesar 153.288 $\mathrm{kg} / \mathrm{tahun}$ atau $91,23 \%$ dari total produksi hiu yang didaratkan. Produksi hiu botol cukup fluktuatif setiap tahun dan cenderung mengalami penurunan. Pada 2011 produksi hiu botol sebesar 77.367 kg, 2012 dan 2013 menjadi $48.960 \mathrm{~kg}$ dan $15.961 \mathrm{~kg}$. Selanjutnya pada 2014 kembali menurun menjadi 11.000 kg (Gambar 1).

Armada penangkap hiu di NTT sebagian besar berukuran kecil dengan ukuran gross tone berkisar antara 2-6 GT dan hanya beberapa armada dengan alat tangkap gill net yang ukuran gross tone-nya berkisar antara 50 - 100 GT. Alat tangkap yang digunakan untuk menangkap hiu adalah rawai dasar, rawai tetap, jaring insang (gill net) dan pancing ulur. Jenis dan jumlah alat tangkap yang digunakan dalam kurun waktu 4 tahun (2011-2014) sangat fluktuatif. Pada 2011 jenis alat tangkap yang beroperasi adalah rawai dasar dan gill net. Rawai dasar yang beroperasi pada tahun ini adalah sebanyak 529 trip dan gill net 34 trip. Pada 2012, alat tangkap yang dioperasikan adalah rawai dasar dan pancing ulur. Jumlah trip rawai dasar pada tahun ini mengalami penurunan dari tahun sebumnya yaitu, 422 trip sedangkan, pancing ulur yang dioerasikan tripnya menapai 618 trip. Jenis alat tangkap yang ditemukan beropeasi pada 2013 hanya rawai dasar dengan jumlah trip yang menurun drastis yaitu, hanya sebanyak 58 trip. Pada 2014, jenis alat tangkap yang digunakan ada tiga jenis yaitu rawai dasar 142 trip, rawai tetap 3 trip dan gill net 1 trip (Gambar 2).

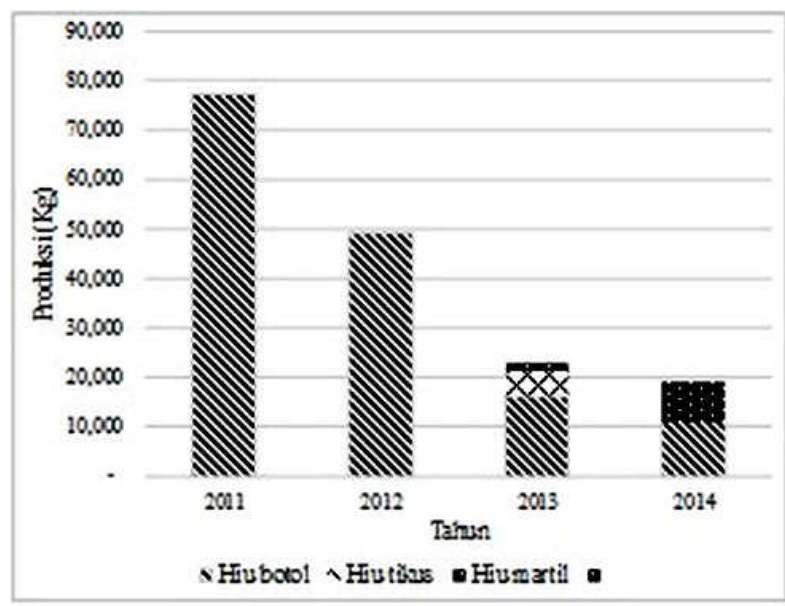

Gambar 1. Total hasil tangkapan hiu menurut jenis di PPP Tenau, pada 2011-2014. Figure 1. Total ctach of shark by species landed at PPP Tenau, in 2011- 2014. 


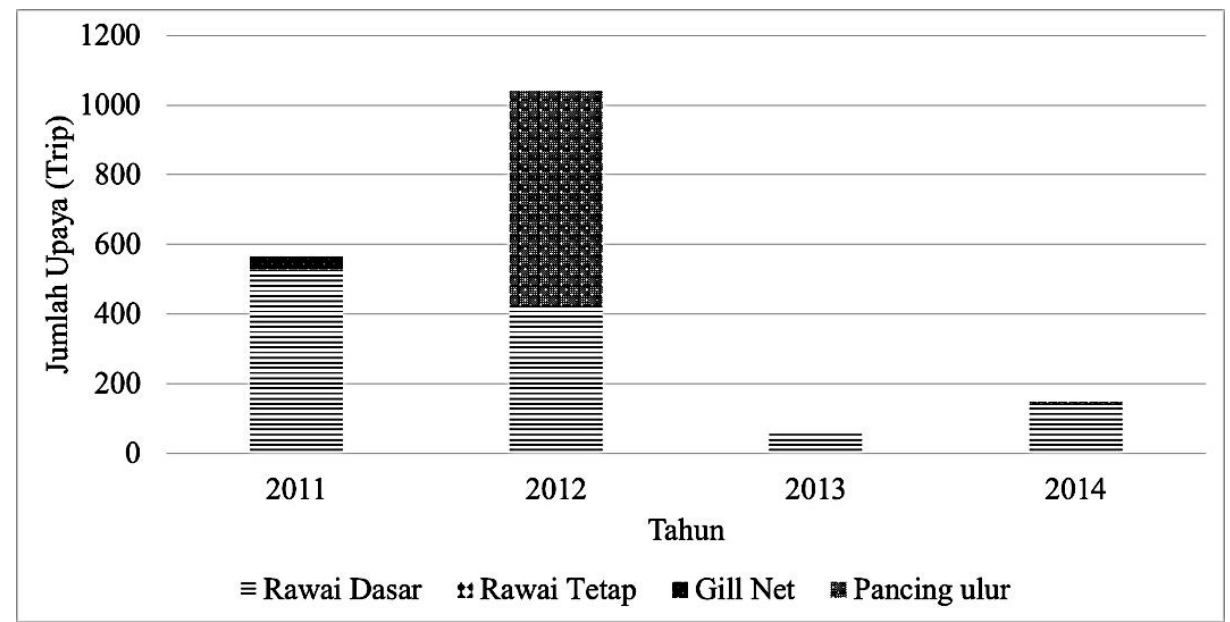

Gambar 2. Jumlah trip menurut jenis alat tangkap periode 2011 - 2014 di PPP Tenau, Kupang.

Figure 2. Number of trips based on gear type in period of 2011-2014 at PPP Tenau, Kupang.

Perbedaan jenis alat tangkap berpengaruh pada jumlah hasil tangkapan. Jumlah total hasil tangkapan dari alat tangkap rawai dasar pada tahu 2011-2014 mencapai $151.293 \mathrm{~kg}$, diikuti oleh gil net sebesar $39.590 \mathrm{~kg}$, kemudian pancing ulur sebesar $1.995 \mathrm{~kg}$ dan rawai tetap $1.480 \mathrm{~kg}$ (Gambar 3).

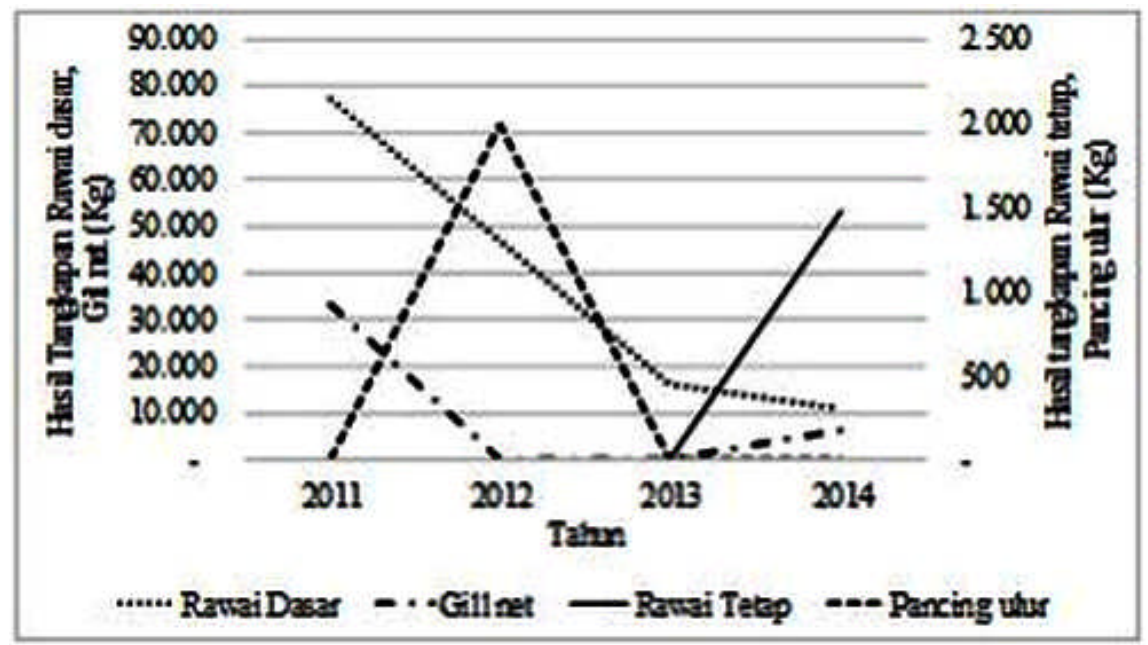

Gambar 3. Hasil tangkapan total hiu per alat tangkap (2011 - 2014) PPP Tenau, Kupang.

Figure 3. Total catch of sharks by fishing gear in period (2011-2014) di PPP Tenau, Kupang.

\section{Perkembangan Catch Per Unit Effort}

Jumlah trip penangkapan hiu botol dengan menggunakan rawai dasar pada tahun 2011 sebanyak 529 trip dengan jumlah hasil tangkapan sebesar 77.367 kg. Trip penangkapan hiu botol dengan menggunakan rawai dasar pada tahun 2012 mengalami penurunan menjadi 422 trip diikuti dengan penurunan produksi yakni $46.965 \mathrm{~kg}$. Sedangkan, produksi hiu botol dengan alat tangkap pancing ulur pada tahun ini adalah sebesar $1.995 \mathrm{~kg}$ dengan trip penangkapan sebanyak 618 trip. Pada tahun 2013 jumlah trip penangkapan hiu botol dengan alat tangkap rawai dasar terus mengalami penurunan menjadi 58 trip. Penurunan trip penangkapan ini mengakibatkan terjadinya penurunan produksi hiu botol menjadi $15.961 \mathrm{~kg}$. Pada tahun 2014 penangkapan hiu botol dengan alat tangkap rawai dasar mengalami peningkatan menjadi 142 trip namun tidak diikuti dengan kenaikan produksi pada tahun tersebut karena produksi hiu botol pada tahun ini hanya sebesar 11.000 $\mathrm{kg}$.

Total hasil tangkapan dari alat tangkap rawai dasar dan pancing ulur pada tahun 2011-2014 berturut-turut sebesar, $77.367 \mathrm{~kg} ; 48.960 \mathrm{~kg} ; 15.961 \mathrm{~kg}$ dan; 11.000 $\mathrm{kg}$. Effort dari kedua alat tangkap ini berturut-turut adalah 529 trip; 440 trip; 58 trip dan; 142 trip. Hasil perhitungan nilai FPI untuk alat tangkap rawai dasar adalah 1 sedangkan pancing ulur adalah 0,29.

Catch Per Unit Effort (CPUE) dari kedua alat tangkap ini pada tahun 2011 sebesar 146,25 kg/trip, namun pada tahun 2012 menurun menjadi $111,29 \mathrm{~kg} /$ 
trip. Pada tahun 2013 terjadi peningkatan menjadi 275,19 kg/trip sedangkan, pada 2014 kembali mengalami penurunan menjadi $77,46 \mathrm{~kg} /$ trip. Fluktuasi produksi, trip (effort) dan CPUE pada tahun 2011-2014 dapat dilihat pada Gambar 4.

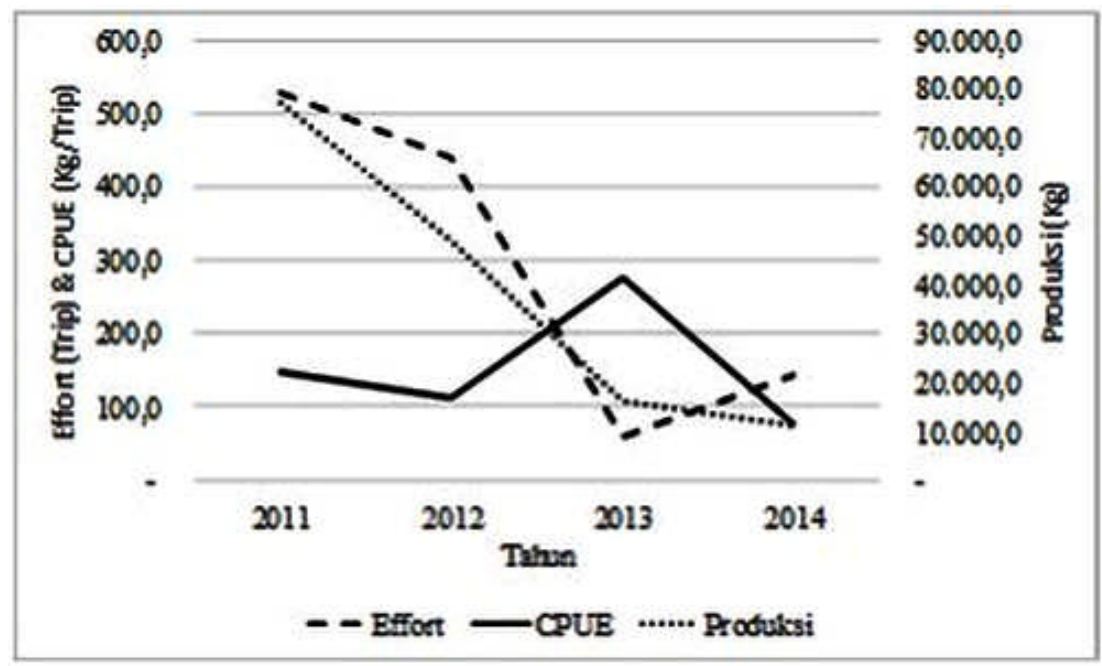

Gambar 4. Fluktuasi hasil tangkapan , upaya, dan nilai Catch per Unit Effort (CPUE) 2011-2014.

Figure 4. Fluctuation of catch, effort and Catch per Unit Effort (CPUE) in 2011-2014.

\section{Daerah dan Musim Penangkapan}

Berdasarkan hasil wawancara dengan nelayan penangkap hiu diperoleh informasi bahwa penangkapan ikan hiu dilakukan di wilayah perairan bagian Selatan Pulau Rote, Timor dan Sabu bahkan sampai ke daerah perbatasan Indonesia-Australia. Daerah penangkapan hiu ini kemudian meluas ke arah timur sampai ke wilayah perairan Maluku bagian Barat Daya dan Tenggara atau pada kisaran titik koordinat antara $120^{\circ}-131^{\circ} \mathrm{BT}$ dan $10^{\circ}-11^{\circ} \mathrm{LS}$. Perkiraan daerah penangkapan hiu disajikan pada Gambar 5.

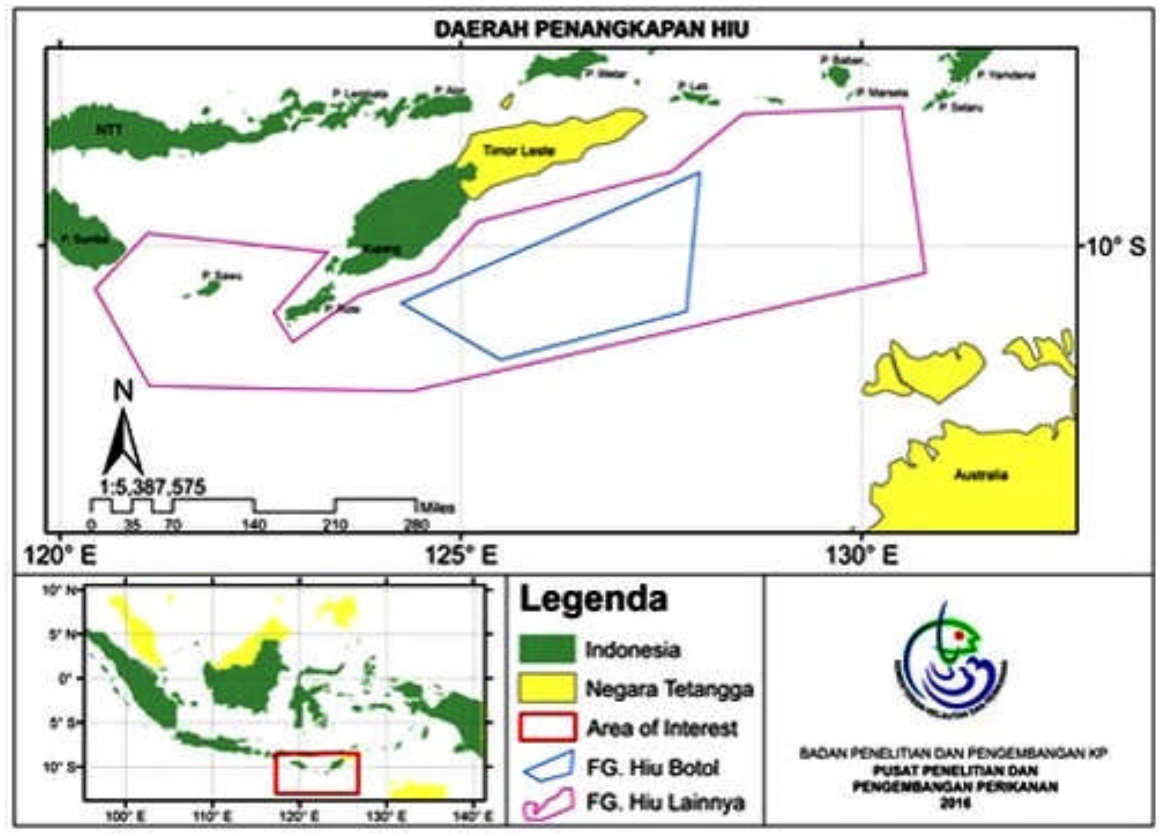

Gambar 5. Perkiraan daerah penangkapan hiu, yang didaratkan di PPP Tenau, Kupang.

Figure 5. Estimated fishing ground of shark landed at PPP Tenau, Kupang.

Aktivitas penangkapan hiu botol di Kupang-NTT berlangsung sepanjang tahun. Hasil tangkapan bulanan dari tahun 2011-2014 sangat fluktuatif. Pada tahun 2011, puncak tangkapan tertinggi terdapat pada bulan Januari dan Agustus. Pada tahun 2012 puncak tangkapan hiu terdapat pada bulan Februari dan Agustus. Pada tahun 2013, puncak tangkapan hiu tertinggi terjadi pada bulan Februari dan September. Sedangkan pada tahun 2014, puncak tangkapan hiu botol terjadi pada bulan Mei dan Maret (Gambar 6). 


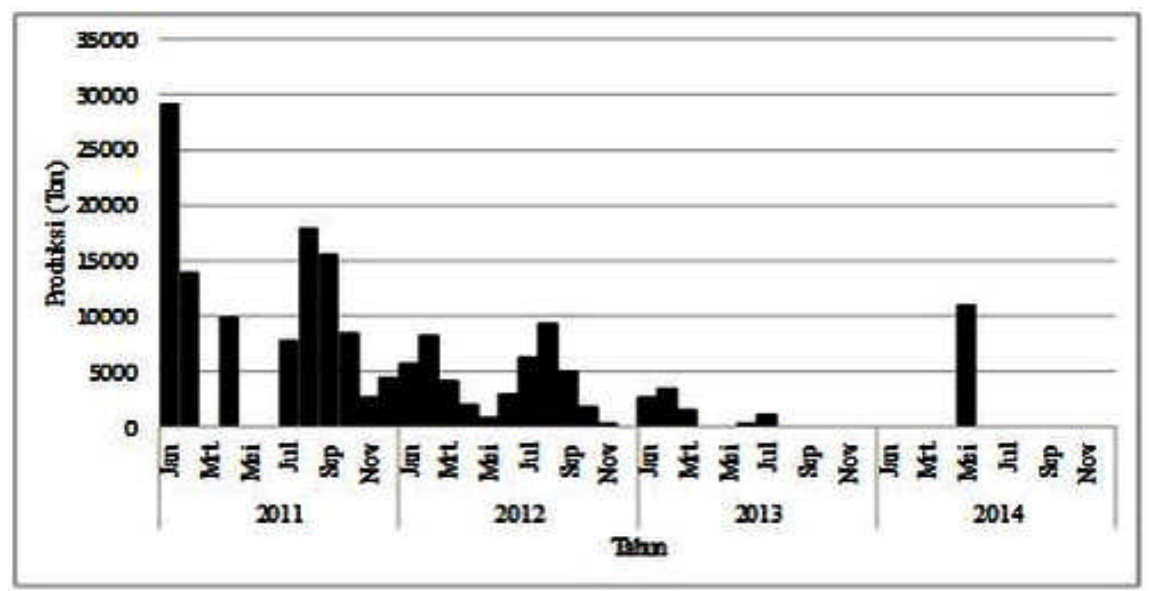

Gambar 6. Hasil tangkapan bulanan hiu yang didaratkan di PPP Tenau, Kupang periode 2011-2014.

Figure 6. Monthly catch of shark landed at Tenau, Kupang during 2011-2014.

\section{Bahasan}

Hiu botol (Centrophorus granulosus, Centrophorus squamosus dan Centroscymnus coelolepis) merupakan jenis hiu yang habitatnya di dasar perairan laut yang dalam. Morfologi hiu botol secara umum yaitu memiliki bentuk tubuh slinder dan sedikit terkompresi, ukuran tubuh variatif dari ukuran terkecil, sedang dan besar dengan ukuran pada saat matang gonad 0,2-6 meter. Memiliki gigi taring tunggal atau bersusun banyak pada rahang atas dan bawah; lima celah insang; dua sirip punggung dengan atau tanpa duri, duri terletak di depan sirip punggung; tidak memiliki sirip anal (Last \& Stevens, 2009; Seret, 2006; McAuley et al., 2002). Beberapa jenis hiu botol dari genus Squalus memiliki duri pada bagian depan sirip punggung mengandung sel-sel vakuolisasi yang mengeluarkan racun (Vidal et al., 2005).

Hiu botol yang didaratkan di PPP Tenau, KupangNTT merupakan hasil tangkapan utama dari perikanan rawai dasar dan merupakan hasil tangkapan sampingan (by catch) dari pancing ulur yang beroperasi di perairan Samudera Hindia. Prosentase hiu botol yang tertangkap rawai dasar selama periode 2011-2014 relatif besar dibandingkan dengan hasil tangkapan jenis hiu lainnya. Hal ini karena nelayan di wilayah NTT menjadikan hiu botol sebagai target utama penangkapan mereka (Gambar 1).

Pada 2011-2013 hasil tangkapan hiu botol dengan rawai dasar dan pancing ulur cenderung menurun. Penurunan jumlah hasil tangkapan ini disertai dengan penurunan jumlah trip. Namun, CPUE dari kedua alat tangkap ini mengalami peningkatan. Berdasarkan hasil wawancara dengan nelayan, pada tahun 2013 jumlah armada penangkap hiu yang mengoperasikan alat tangkap rawai dasar mengalami penurunan. Penurunan ini karena nelayan penangkap hiu di
Kupang yang sifatnya nelayan andon kembali pulang ke daerah asalnya yaitu Sulawesi Tenggara. Pada tahun 2014 jumlah trip penangkapan hiu botol mengalami peningkatan yang signifikan sedangkan jumlah produksi mengalami penurunan dan juga diikuti oleh penurunan CPUE yang tajam. Pada periode tersebut sebagian besar nelayan di NTT yang semula menggunakan alat tangkap rawai apung dengan target tangkapan untuk kelompok hiu oseanik beralih ke alat tangkap rawai dasar dengan sasaran tangkap kelompok hiu botol. Hal ini terjadi akibat dampak keputusan sidang Co-P 16 CITES pada Maret 2013 yang menetapkan beberapa jenis hiu oseanik masuk dalam apendik II CITES, kemudian keputusan tersebut ditindak lanjuti dengan diterbitkannya peraturan menteri KP No. 59 Kepmen KP/2014 tentang pelarangan perdagangan produk hiu ke luar negeri untuk jenis hiu martil (Hammerhead sharks) dan hiu koboi (Whitetip shark), dimana kedua kelompok jenis hiu tersebut termasuk hiu oseanik. Berdasarkan hal tersebut maka terjadi peningkatan hasil tangkapan yang signifikan terhadap kelompok hiu botol.

Berdasarkan data statistik Direktorat Jenderal Perikanan Tangkap periode 2005-2013, jenis-jenis hiu yang tertangkap di wilayah Samudera Hindia (WPP 573) terdiri dari empat famili yaitu, Centrophoridae/ Squalidae (hiu botol), Carcharinidae (hiu lonjor, hiu koboi), Sphyrnidae (hiu marti//hiu caping), dan Alopidae (hiu tikus/hiu monyet). Total produksi tertinggi pada periode ini yaitu dari kelompok jenis dogfish shark sebesar $44,99 \%$ dan yang terendah dari kelompok jenis hammerhead sharks 4,22\%. Produksi dogfish shark di Samudera Hindia pada 2005-2013 berfluktuatif setiap tahunnya. Pada 2005-2007 produksi dog fish shark mengalami peningkatan dimana pada 2007 produksi dogfish shark mencapai $34,80 \%$ dari total produksi periode ini. Setelah tahun 2007 produksinya mengalami penurunan yang darstis dimana pada 
tahun 2013 produksi hiu botol hanya sebesar 3,03\%. Widodo \& Mahulette (2012) menyebutkan bahwa penurunan poduksi ini juga terjadi pada beberapa jenis hiu oseanik seperti hiu tikusan (Alopias vulpinus, Alopias pelagicus dan Alopias superciliosus), sering tertangkap rawai tuna dengan prosentase hasil tangkapan yang sangat rendah yaitu antara 0,1-0,6 $\%$ dan 0,1-1,3. Menurut Zainudin (2011), sumber daya perikanan hiu di Indonesia mengalami penurunan, dengan indikatornya yaitu: a) CPUE mengalami penurunan hingga $26-50 \%$ dibanding dengan hasil tangkapan 10 tahun yang lalu; b) sebagian besar nelayan (44\%) menyatakan bahwa setiap tahun lokasi tangkapnya semakin jauh; dan c) semakin marak dan tingginya tingkat penangkapan hiu di Indonesia.

Berdasarkan hasil wawancara dengan nelayan di Tenau, Kupang, permintaan produk hiu botol berupa squalen sejak lima tahun terakhir terus meningkat. Permintaan terhadap hiu di pasar domestik dan asing cukup tinggi. Restoran, hotel, resort di Indonesia menggunakan hiu dalam menunya, di Tiongkok, sirip hiu digunakan untuk sajian dalam pernikahan adat, sedangkan di Jepang hiu digunakan sebagai obat herbal untuk kanker (Saraswati, 2016). Permintaan serta harga jual hiu yang tinggi memicu IUU fishing terhadap hiu (overfishing, by catch, dan shark finning), bahkan Indonesia menempati urutan pertama negara pemburu hiu terbesar 2002-2011 (Lack \& Sant, 2012).

Status populasi hiu botol yang sebenarnya dapat diketahui melalui penelitian secara runut waktu. Penurunan populasi suatu spesies indikatornya antara lain yaitu, ukuran ikan yang tertangkap semakin kecil, daerah penangkapan semakin jauh dan menurunnya hasil tangkapan atau CPUE. Clarke et al., (2006) mengemukakan bahwa, hal utama untuk mengetahui jumlah hasil tangkapan hiu dan untuk pengembangan prospek pasar perdagangan hiu dibutuhkan data yang lengkap dan komperhensif. Beberapa alternatif yang dapat digunakan sebagai solusi untuk pengelolaan sumber daya yang telah mengalami perubahan dalam hal penurunan populasi dapat dilakukan dengan cara pembatasan izin penangkapan, pengaturan jenis alat tangkap dan musim pelarangan penangkapan (Pérez \& Ménez, 2015). Dell'Apa et al., (2013) mengungkapkan bahwa perdagangan hiu secara internasional telah memberikan dampak yang buruk bagi keberlanjutan hiu dan secara tidak langsung akan berakibat bagi rusaknya ekosistem perairan.
Berdasarkan data dari IUCN (2016), terdapat 119 jenis hiu botol yang tersebar di seluruh perairan di dunia. Di wilayah perairan Australia secara umum ditemukan bahwa, hiu botol dari jenis Centroscymnus coelolepis memiliki tingkat tangkapan yang tertinggi pada kedalaman lebih dari 1.000 m (Graham \& Daley, 2011). Centrophorus squamosus ditemukan di bagian dasar lereng benua pada kedalaman antara 230 sampai dengan 2.400 meter, sedangkan Centrophorus granulosus sering ditemukan pada kedalaman 200600 meter (Compagno, 1984). Di wilayah perairan Timur Indonesia hiu botol dari jenis Centrophorus squamosus, Centroscymnus coelolepis dan Centrophorus granulosus tertangkap pada kedalaman antara 200-800 meter. Perbedaan kedalaman dimana hiu botol tertangkap di perairan Indonesia dan Australia diduga karena adanya perbedaan hidrografi dan kondisi karakteristik perairannya.

Hasil tangkapan hiu botol yang tertinggi di wilayah perairan Selatan Pulau Rote, Timor dan Sabu ditemukan pada bulan Januari-Februari dan bulan Agustus-September. Kemudian pada bulan selanjutnya karena kondisi laut dengan ombak besar dan angin kencang akibat dari pengaruh musim barat maka, terjadi pergeseran atau perpindahan daerah penangkapannya ke arah timur, ke wilayah perairan Maluku bagian Barat Daya dan Tenggara Barat.

Berdasarkan informasi dari nelayan, posisi geografis hiu botol yang tertangkap terdapat pada koordinat $124^{\circ}-128^{\circ}$ BT dan $10^{\circ}-11^{\circ}$ LS dengan kedalaman antara 200-800 meter. Sedangkan jenis hiu lainnya seperti hiu martil (Sphyrnidae) menyebar hampir diseluruh wilayah perairan yang berbatasan dengan Australia pada kedalaman 70-80 meter, dan hiu koboi (Carcharhinus longimanus) terdapat pada koordinat $120^{\circ}-122^{\circ} \mathrm{BT}$ dan $10^{\circ}-11^{\circ} \mathrm{LS}$, dengan kedalaman berkisar 50-80 meter.

Berdasarkan hasil wawancara dengan nelayan diketahui bahwa, hiu botol yang dalam kondisi matang gonad-hamil biasanya akan tertangkap pada bulan Maret, April, Mei, September, Oktober, dan Nopember. Pada bulan Maret-April, hiu yang tertangkap dalam kondisi matang gonad dapat mencapai $15 \%$ dari total hasil penangkapan. Penangkapan hiu botol dalam kondisi demikian akan berpengaruh negatif terhadap stok dari populasi dan keberlanjutannya di alam. 
Kondisi demikian dapat terjadi recruitment over fishing yaitu, terjadinya pengurangan ketersediaan kelompok ikan dalam kondisi matang gonad karena penambahan individu yang dihasilkan tidak cukup untuk mempertahankan populasi. Menurut Taylor et al. (2013), stok hiu di suatu perairan dipengaruhi oleh jumlah hiu betina yang akan memberikan pengaruh positif bagi kenaikan jumlah rekruitmen. Spare \& Venema (1992) menyatakan bahwa proses rekruitmen suatu spesies kemungkinan dipengaruhi oleh beberapa faktor, yaitu daerah penangkapan, alat tangkap yang digunakan dan ukuran yang tertangkap. Proses rekruitmen dapat juga dipengaruhi oleh faktor kualitas lingkungan perairan, densitas induk yang tersedia, dan ada tidaknya pemangsa atau predator (Dharmadi \& Fahmi, 2007b) serta ketersediaan ekosistem yang tidak mengalami tekanan (Morgan \& Sulikowski, 2015).

\section{KESIMPULAN}

Hiu botol yang menjadi target penangkapan nelayan penangkap hiu di Kupang, Nusa Tenggara Timur terdiri atas tiga jenis yakni: Centrophorus squamosus (10-13\%), Centrophorus granulosus (15$20 \%$ ), dan Centroscymnus coelolepis (40\%). Jumlah dari hiu botol yang tertangkap rawai dasar di Samudera Hindia berkisar 0,01-0,04 \% dari total penangkapan ikan yang didaratkan di Tenau. Produksi hiu botol dalam empat tahun terakhir cenderung mengalami penurunan sehingga diperlukan pengelolaan terkait jumlah kuota dan ukuran hiu botol yang boleh ditangkap. Daerah penangkapan hiu botol yang potensial di wilayah Samudera Hindia adalah pada koordinat $124^{\circ}-128^{\circ}$ BT dan $10^{\circ}-11^{\circ}$ LS dan pada kedalaman antara 200-800 meter.

\section{PERSANTUNAN}

Tulisan ini merupakan kontribusi dari kegiatan penelitian "Kajian Mengenai Efektifitas Implementasi Kebijakan Konservasi Hiu dan Mamalia Laut (WPP 573)" Tahun Anggaran 2016, di Pusat Penelitian dan Pengembangan Perikanan - Jakarta.

\section{DAFTAR PUSTAKA}

Badrudin. (2015). Analisis Data Catch dan Effort untuk Pendugaan Maximum Sustainable Yield (MSY) (p.
81-93). Protokol Pengkajian Stok Sumber Daya Ikan. Puslitbangkan. Jakarta.

Clarke, S. C., Mc Allister, M. K., Milner-Gulland, E. J., Kirkwood, G. P., Michielsens, Catherine, G. J., Agnew, D. J., Pikitch, E. K., Nakano, H., \& Shivji, M. S. (2006). Global estimates of shark catches using trade records from commercial markets. Ecology Letters. 9, 1115-1126.

Compagno, L. J. V. (1984). FAO Species catalogue. Vol. 4. Sharks of the world. An annotated and illustrated catalogue of shark species known to date. Part 1- Hexanchiformes to Lamniformes. FAO Fish. Synop. 125(4/1):1-249. Rome: FAO.

Damongilala, L. J. (2008). Kandungan asam lemak tak jenuh minyak hati ikan cucut botol (Cenctrophorus sp) yang diekstraksi dengan cara pemanasan. JIS. 8(2), 249-253.

Dinas Kelautan dan Perikanan Provinsi Nusa Tenggara Timur. Statistik perikanan tangkap periode 2014.

Dell'Apa, A., Johnson, J. C., Kimmel, D.G., \& Rulifson, R. A. (2013). The international trade and fishery management of spiny dogfish: A social network approach. Ocean \& Coastal Management. 80, 65 -72 .

Dharmadi \& Fahmi. (2007a). Aspek biologi dan daerah penangkapan cucut botol (Squalus sp.) yang tertangkap di perairan Samudera Hindia. J.Lit.Perik. Ind. 13(1) 35-42.

Dharmadi \& Fahmi. (2007b). Distribusi frekuensi panjang, hubungan panjang tubuh, panjang klasper, dan nisbah kelamin cucut lanjaman (Carcharhinus falciformis). J.Lit.Perik. Ind. 13 (2), 243-249.

Dharmadi, Fahmi., \& William, W. (2009). Biodiversity of sharks and rays in south-eastern Indonesia. Ind. Fish.Res.J. 15(2), 17-28.

Fahmi \& Dharmadi (2013). A review of the status of shark fisheries and shark conservation in Indonesia [in Bahasa]. Jakarta: Direktorat Konservasi Kawasan dan Jenis Ikan, Kementerian Kelautan dan Perikanan. $187 \mathrm{p}$. 
Garcia, V.B., Lucifora, L. O., \& Myers, R.A. (2008). The importance of habitat and life his-tory to extinction risk in sharks, skates, rays and chimaeras. $\mathrm{P}$ roc. R. Soc. London,Ser. B: Biol. Sci. 275, 83-89.

Graham, K.J., \& Daley, R. K. (2011). Distribution, reproduction and population structureof three gulper sharks (Centrophorus, Centrophoridae) in southeast Australianwaters. Mar. Freshwater Res. $62,583-595$.

IUCN Red List (August, 2016). http:// www.iucnredlist.org/

Kyne, P. M., \& Simpfendorfer, C. A. (2010). Deepwater chondrichthyans. In: Carrier, J.C.,Musick, J.A., Heithaus, M.R. (Eds.), Sharks and Their Relatives II-Biodiversity, Adaptive Physiology, and Conservation. CRC Press, Boca Raton, FL, p. 37113.

Lack, M \& Sant, G. (2012). An Overview of Shark Utilisation in the Coral Triangle Region (p.46). TRAFFIC \& WWF. 2012.

Last, P. R., \& Stevens, J. D. (2009). Sharks and rays of Australia (p. 644). CSIRO, Australia.

McAuley R., Newbound, D., \& Ashwort R. (2002). Field identification guide to Western Australian Sharks and Shark-like Rays (p. 25). Departement of Fisheries, Government of Western Australia.

Morgan, A.C., \& Sulikowski, J.A. (2015). The role of spiny dogfish in the northeast United States continentalshelf ecosystem: How it has changed over time and potentialinterspecific competition for resources. Fisheries Research. 167, 260-277.
Pelabuhan Perikanan Pantai Tenau, Kupang - Nusa Tenggara Timur. Statistik perikanan tangkap periode 2011-2014.

Pérez-Jiménez, J. C., \& Mendez. (2015). The smallscale shark fisheries in the southern Gulf of Mexico: Understanding their heterogeneity to improve their management. Fisheries Research. $172,96-104$.

Saraswati, W. K. (2016). Respon Pemerintah Indonesia terkait sekuritisasi WWF melalui kampanye Save Our Sharks. Journal of International Relations. 2 (4), 68-77.

Seret, B. (2006). Identification guide of the main shark and ray species of the eastern tropical Atlantic, for the purpose of the fishery observers and biologists (P.75). Fondation Internationale du Banc d'Arguin (FIBA).

Simpfendorfer, C. A., \& Kyne, P. M. (2009). Limited potential to recover from overfishingraises concerns for deep-sea sharks, rays and chimaeras. Environ. Conserv. 36, 97-103.

Spare, P., \& Venema, S. C. (1992). Introducsion to tropical fish stock assessment. Part I: Manual. FAO Fish. Tech. Pap. No. 306/1.

Stevens, J. D., Bonfil R., Dulvy, N. K., \& Walker P. A. (2000). The effects of fishing on sharks, rays, and chimaeras (chondrichthyans), and the implications for marine ecosystem. ICES Journal of Marine Science. 57, 476-494.

Taylor, I. G., Gertseva, V., Methot Jr. Richard, D., \& Maunder, M. N. (2013). A stock-recruitment relationship based on pre-recruit survival, illustrated with application to spiny dogfish shark. Fisheries Research. 142, 15-21. 
Vidal, H. Jr., \& Otto, B. F. G. (2005). The spiny dogfish (Squalus cubensis/megalops group): The envenoming of a fisherman, with taxonomic and toxinological comments on the Squalus genus. Toxicon. 46, 828-830.

Widodo, A. A. \& Mahulette, R. T. (2012). Jenis, ukuran dan daerah penangkapan hiu Thresher (famili
Alopiidae) yang tertangkap rawai tuna di Samudera Hindia. BAWAL, 4 (2), $75-82$.

Zainudin, I. M. (2011). Pengelolaan perikanan hiu berbasis ekosistem di Indonesia. Tesis. FMIPA Universitas Indonesia. p. 84. 